\title{
DETERMINAN KETAHANAN MODAL BANK SYARIAH DI INDONESIA: PENDEKATAN ECM
}

\author{
Giras Risti Wilara, Agus Tri Basuki \\ Program Studi Ekonomi Pembangunan \\ Fakultas Ekonomi, Universitas Muhammadiyah Yogyakarta \\ Email Korespondensi: agustri.umy@gmail.com
}

Naskah Diterima: Juli 2016; Disetujui: Oktober 2016

\begin{abstract}
This research aims to analyze the impact of Return on Assets (ROA), Financing to Deposit Ratio (FDR), Operational Expense to Operational Income (BOPO), and inflation on Capital Adequacy Ratio (CAR) in both short and long term. The object of this research is Shari'ah Banks in Indonesia by gaining the data from January 2013 to June 2015 from information published by some institutions such as Financial Services Authority (OJK) and Central Bureau of Statistics (BPS). The data were analyzed by Error Correction Model (ECM) method. Based on the analysis, the result shows that ROA and Inflation have positive and significant influence toward CAR, FDR has positive and negative influence toward CAR, whereas BOPO has no influence toward CAR. Besides, there is a short term and long term relationship between ROA, FDR, and inflation toward CAR.

Keywords: Shari'ah bank, Capital Adequacy Ratio, ECM model

JEL Classifications: G21, C80, G32

Abstrak: Penelitian ini bertujuan untuk menganalisis bagaimana pengaruh Return on Assets (ROA), Pembiayaan terhadap Rasio Deposito (FDR), Biaya Operasional terhadap Pendapatan Operasional (BOPO), dan Inflasi terhadap Capital Adequacy Ratio (CAR) baik dalam jangka pendek maupun jangka panjang. Objek penelitian ini adalah Bank Syariah di Indonesia dengan memperoleh data selama bulan Januari 2013-Juni 2015. Dalam penelitian ini, sampel sebanyak 30 data didapat dari informasi yang diterbitkan oleh beberapa institusi seperti Otoritas Jasa Keuangan (OJK) dan Biro Pusat Statistik (BPS). Data dianalisis dengan metode analisis Error Correction Model (ECM). Berdasarkan hasil analisis, hasil penelitian menunjukkan bahwa ROA dan Inflasi berpengaruh positif dan signifikan terhadap CAR, FDR berpengaruh positif dan negatif terhadap $C A R$, sedangkan BOPO tidak berpengaruh signifikan terhadap CAR. Selain itu, ada hubungan jangka pendek dan panjang antara ROA, FDR, dan inflasi terhadap CAR.

Keywords: bank syariah, Capital Adequacy Ratio (CAR), model ECM

Klasifikasi JEL: G21, C80, G32
\end{abstract}




\section{PENDAHULUAN}

Indikator kesehatan perbankan yang sangat penting yaitu indikator modal. Indikator modal perbankan harus dikedepankan mengingat dalam mekanismenya perbankan merupakan industri yang usahanya mengandalkan kepercayaan masyarakat. Kesehatan bank yang dapat dilihat dengan indikator modal sudah seharusnya dipergunakan masyarakat untuk membangun kepercayaan dalam menyerahkan dananya pada bank. Hal ini mengingat citra perbankan nasional yang ternodai oleh berbagai kasus penyelewengan dana nasabah oleh pihak manajemen bank, maupun masalah perbankan yang tidak liquid (Fatimah, 2014).

Penilaian tingkat kesehatan bank di Indonesia saat ini secara garis besar didasarkan pada faktor CAMEL (Capital, Assets Quality, Management, Earning dan Liquidity). Kelima faktor tersebut merupakan faktor yang menentukan kondisi suatu bank. Apabila suatu bank mengalami permasalahan yang menyangkut salah satu faktor tersebut, maka akan mengalami kesulitan.

Dalam dunia perbankan, modal merupakan salah satu bagian terpenting untuk mengetahui kondisi kesehatan bank. Sehat atau tidaknya sebuah bank akan menentukan pula kondisi perbankan yang akan datang apakah masih bertahan atau mengalami kebangkrutan. Secara sederhana, bank yang sehat adalah bank yang dapat menjaga dan memelihara kepercayaan masyarakat, dapat menjalankan fungsi intermediasi, dapat membantu kelancaran lalu lintas pembayaran serta dapat digunakan oleh pemerintah dalam melaksanakan berbagai kebijakan.

Demi menciptakan perbankan yang sehat, BI telah mengeluarkan program Arsitektur Perbankan Indonesia (API) yaitu program penguatan struktur perbankan nasional yang bertujuan untuk memperkuat permodalan bank dalam rangka meningkatkan kemampuan bank mengelola usaha maupun resiko. Upaya pemerintah yang lain yaitu dengan dikeluarkannya Peraturan Bank Indonesia Nomor: 6/10/PBI/2004 tentang Sistem Penilaian Tingkat Kesehatan Bank Umum. Ketentuan yang salah satu diantaranya adalah mengatur tentang permodalan Bank (CAR) minimum sebesar $8 \%$.

Salah satu cara untuk menguji kecukupan modal adalah dengan melihat rasio modal itu terhadap berbagai aset bank yang bersangkutan, yakni melalui CAR (Capital Adequacy Ratio). Penilaian tersebut dapat diukur dengan dua cara, yaitu membandingkan modal dengan dana-dana pihak ketiga dan membandingkan modal dengan aktiva berisiko. Dalam perjalanannya, rasio kecukupan modal (CAR) pada perbankan syariah perlu memperhatikan faktor eksternal dan internal yang dapat mempengaruhi kegiatan mereka. Salah satu faktor eksternal yang berkaitan dengan kecukupan modal (CAR) adalah inflasi.

Semenatara itu, faktor internal yang harus diperhatikan oleh bank syariah dalam memperhatikan kesehatan bank meliputi profitabilitas, likuiditas, dan efisiensi. Untuk memenuhi kecukupan modal minimum atau untuk standar CAR yang sehat, maka bank harus mampu menghasilkan profit atau yang biasa disebut profitabilitas. Rasio profitabilitas merupakan aspek untuk mengetahui kemampuan bank dalam menghasilkan keuntungan. Penilaiannya dapat dilakukan dengan menggunakan Rasio Return On Assets (ROA). Masalah profitabilitas ini sangat penting bagi perkembangan suatu bank karena menyangkut masalah kepercayaan masyarakat yang akan menyimpan dananya di bank.

Salah satu cara bank untuk memaksimalkan profitabilitasnya adalah dengan memperhatikan tingkat likuiditas perusahaannya. Melihat fenomena perbankan di Indonesia tidak likuid 
karena CAR yang tidak mencukupi, dapat dilihat bahwa terdapat hubungan antara rasio likuiditas dengan CAR, di mana likuiditas merupakan kemampuan bank dalam memenuhi kewajiban jangka pendeknya saat ditagih (Kasmir, 2009).

Dalam hal ini, likuiditas tersebut dijelaskan oleh Financing to Deposit Ratio (FDR), yaitu rasio antara seluruh jumlah pembiayaan yang diberikan dengan dana yang diterima bank (Dendawijaya, 2005). Berdasarkan pengertian tersebut, dapat dilihat hubungan FDR dengan CAR, yaitu saat FDR tinggi yang disebabkan pembiayaan tinggi sedangkan dana yang dihimpun sedikit dapat menyebabkan CAR menurun (dengan asumsi CAR digunakan untuk menutupi kekurangan dana tersebut).

BOPO diukur secara kuantitatif dengan menggunakan rasio efisiensi. Rasio ini mengukur apakah manajemen bank telah menggunakan semua faktor produksinya dengan efektif dan efisien. Ada pun, efisien usaha bank diukur melalui biaya operasional yang dibandingkan dengan pendapatan operasional (BOPO). BOPO merupakan rasio perbandingan biaya operasional terhadap pendapatan operasional. Rasio ini digunakan untuk mengukur tingkat efisiensi dan kemampuan bank dalam melakukan kegiatan operasinya terutama kredit (Dendawijaya, 2005). Sama halnya dengan ROA, secara teoritis BOPO juga memiliki hubungan dengan $\mathrm{CAR}$, dengan asumsi semakin efisien bank menghasilkan laba melalui biaya operasionalnya, semakin meningkat pula modal yang ditanamkannya.

Selama periode pengamatan (Januari 2013 Juni 2015) perkembangan variabel-variabel yang digunakan dalam penelitian ini dapat dilihat dari tabel dibawah ini:

Tabel 1. Perkembangan CAR, ROA, FDR, BOPO, dan Inflasi pada Bank Umum Syariah Indonesia Periode 2012-2014

\begin{tabular}{cccccc}
\hline Tahun & $\begin{array}{c}\text { CAR } \\
\text { (persen) }\end{array}$ & $\begin{array}{c}\text { ROA } \\
\text { (persen) }\end{array}$ & $\begin{array}{c}\text { FDR } \\
\text { (persen) }\end{array}$ & $\begin{array}{c}\text { BOPO } \\
\text { (persen) }\end{array}$ & $\begin{array}{c}\text { Inflasi } \\
\text { (persen) }\end{array}$ \\
\hline $\mathbf{2 0 1 2}$ & $14,13 \%$ & $2,14 \%$ & $100,00 \%$ & $74,97 \%$ & $4,30 \%$ \\
\hline $\mathbf{2 0 1 3}$ & $14,42 \%$ & $2,00 \%$ & $100,32 \%$ & $78,21 \%$ & $8,38 \%$ \\
\hline $\mathbf{2 0 1 4}$ & $15,74 \%$ & $0,79 \%$ & $91,50 \%$ & $94,16 \%$ & $8,36 \%$ \\
\hline
\end{tabular}

Sumber: Bank Indonesia

Berdasarkan tabel di atas, dapat dilihat bahwa perolehan rata-rata CAR Bank Umum Syariah mengalami kenaikan setiap tahunnya, yaitu sebesar 14,13\% pada tahun 2012, lalu sedikit naik pada tahun 2013 menjadi 14,42\%, dan naik pada tahun 2014 menjadi 15,74\%. Hal ini menunjukkan bahwa rata-rata rasio CAR berada di atas 8\% sehingga dapat dikatakan bahwa kondisi permodalan bank umum syariah di Indonesia selama periode 2012-2014 berada dalam kondisi sehat.

Rata-rata ROA Bank Umum Syariah Indonesia pada tahun 2012-2014 cenderung menurun. Seperti yang dilihat pada tabel 1, nilai
ROA pada tahun 2012 sebesar 2,14\% dan terus menurun hingga tahun 2014 sebesar 0,79\%. Hal ini menunjukkan hubungan negatif dengan CAR, di mana menurunnya ROA diikuti meningkatnya CAR. Semakin besar ROA suatu bank, semakin besar pula tingkat keuntungan yang dicapai bank tersebut dan semakin baik pula posisi bank tersebut dari segi penggunaan asset sehingga CAR yang merupakan indikator kesehatan bank menjadi berkurang nilainya dan sebaliknya jika bank meraih untung maka modalnya akan bertambah (Masyhud, 2006).

Rata-rata FDR Bank Umum Syariah Indonesia pada tahun 2012-2014 cenderung fluktuatif, seperti yang dilihat pada tabel 1 bahwa nilai FDR pada tahun 2012 dari 100,00\% naik 
menjadi 100,32\% pada tahun 2013 lalu menurun di tahun 2014 menjadi 91,50\%. Penurunan FDR tesebut disebabkan kondisi makro-ekonomi yang belum stabil, sehingga perbankan syariah membatasi pembiayaan. Namun, berdasarkan surat edaran Bank Indonesia No 26/5/BPPP tanggal 29 Mei 1993, besarnya FDR telah ditentukan oleh Bank Indonesia tidak boleh melebihi 110\% (Muhammad, 2005:55). Hal ini menunjukkan bahwa rata-rata FDR pada tahun 2012-2014 berada di bawah 110\% sehingga dapat dikatakan kondisi FDR bank umum syariah di Indonesia selama periode 2012-2014 dalam kondisi yang baik.

Rata-rata BOPO Bank Umum Syariah Indonesia pada tahun 2012 mencapai 74,97\% dan cenderung mengalami peningkatan hingga akhir tahun 2014, yaitu mencapai 94,16\%. Hal ini menunjukkan hubungan yang positif dengan CAR, di mana meningkatnya BOPO diikuti meningkatnya CAR. Dengan asumsi semakin efisien bank menghasilkan laba melalui biaya operasionalnya, semakin meningkat pula modal yang ditanamkannya.

Rata-rata Inflasi di Indonesia pada tahun 2012-2014 cenderung fluktuatif, yakni pada tahun 2012 nilainya mencapai 4,30\%, kemudian meningkat pada tahun 2013 menjadi 8,38\% lalu sedikit menurun menjadi 8,36\% di tahun 2014 . Keadaan inflasi yang tinggi menunjukkan hubungan positif dengan CAR mengingat ketika tingkat inflasi tinggi, kecenderungan harga barang-barang menjadi naik sehingga pemerintah akan menerapkan kebijakan moneter untuk mengatasi masalah tersebut dengan cara menaikkan suku bunga perbankan agar masyarakat menabung di bank. Dengan masuknya dana masyarakat yang dihimpun oleh bank, maka akan semakin bagus tingkat kesehatan modal bank itu sendiri dan nilainya akan jauh dari tingkat minimum.
Definisi Bank Syariah menurut Muhammad (2000:62) adalah bank yang beroperasi tanpa mengandalkan bunga. Bank tersebut merupakan lembaga keuangan yang kegiatan operasional dan produknya dikembangkan berlandaskan pada AlQuran dan Hadits Nabi Muhammad SAW. Dengan kata lain, Bank Syariah adalah lembaga keuangan yang usaha pokoknya memberi pembiayaan dan jasa-jasa lainnya dalam lalu lintas pembayaran serta peredaran uang yang pengoperasiannya disesuaikan dengan prinsipprinsip Syariat Islam.

Penelitian Edginarda (2012) menunjukkan bahwa ROA berpengaruh signifikan positif, BOPO signifikan negatif, sementara LDR tidak berpengaruh terhadap CAR pada kasus bankbank pemerintah di Indonesia selama periode 2003-2010. Secara simultan ROA, BOPO, dan LDR berpengaruh terhadap CAR.

Sementara itu, penelitian Sakinah (2013) menyimpulkan bahwa ROA, FDR, dan Inflasi secara parsial memiliki pengaruh positif dan signifikan terhadap CAR, nilai tukar secara parsial tidak berpengaruh terhadap CAR pada kasus bank syariah di Indonesia selama periode Maret 2009-Desember 2011. Secara simultan, ROA, FDR, nilai tukar, dan inflasi bersama-sama berpengaruh terhadap CAR.

Sama halnya dengan penelitian Fatimah (2014), disimpulkan bahwa ROA berpengaruh negatif signifikan terhadap CAR, BOPO berpengaruh positif signifikan, dan FDR berpengaruh negatif signifikan terhadap CAR untuk kasus bank umum syariah di Indonesia. Selain itu, terdapat pula hubungan jangka panjang antara BOPO dan FDR terhadap CAR, sementara dalam jangka pendek terdapat hubungan antara ROA, BOPO dan FDR terhadap CAR.

Penelitian Yuliyani (2015) menyatakan bahwa secara parsial ALR dan BOPO berpengaruh signifikan terhadap $\mathrm{CAR}$, namun 
QR dan ROA tidak berpengaruh signifikan untuk kasus bank Umum yang terdaftar di BEI selama periode 2009-2013. Secara simultan ALR, QR, ROA, dan BOPO terbukti berpengaruh signifikan terhadap CAR.

\section{METODE PENELITIAN}

Dalam menganalisis besarnya pengaruh ROA, FDR, BOPO, dan inflasi terhadap CAR pada Bank Umum Syariah di Indonesia, model ECM (Error Correction Model) dipergunakan dalam penelitian ini. Model ECM ini mampu menguji konsisten tidaknya model empiris dengan teori ekonomi serta dalam pemecahannya terhadap variabel runtut waktu yang tidak stasioner dan regresi lancung. Error Correction Model juga merupakan alat ekonometrika yang digunakan dengan tujuan untuk mengidentifikasikan hubungan jangka panjang $\Delta L_{n} C A R_{t}=\beta_{0}+\beta_{1} \Delta R O A_{t}+\beta_{2} \Delta F D R_{t}+\beta_{3} \Delta B O P O_{t}+\beta_{4} \Delta I N F_{t}+E C T+\mu_{t}$

Keterangan:

$\mathrm{L}_{\mathrm{n}} \mathrm{CAR}_{\mathrm{t}} \quad=$ Capital Adequacy Ratio

$\mathrm{ROA}_{\mathrm{t}} \quad=$ Return On Assets

$\mathrm{FDR}_{\mathrm{t}} \quad=$ Financing to Deposit Ratio

$\mathrm{BOPO}_{\mathrm{t}}=$ Operational Expense to Operational

Income

$\mathrm{INF}_{\mathrm{t}} \quad=$ Inflasi

$\beta_{0} \quad=$ Intercept $/$ konstanta

$\mu_{\mathrm{t}} \quad=$ Residual

$\Delta \quad=$ Perubahan

$\mathrm{t} \quad=$ Periode waktu

ECT = Error Correction Term

\section{HASIL DAN PEMBAHASAN}

1. Hasil Uji Stasionaritas Data

Sebelum melakukan regresi dengan uji ECM, terlebih dahulu dilakukan uji stasionaritas untuk mengetahui apakah variabel yang digunakan telah stasioner atau tidak. Bila data tidak stasioner maka akan diperoleh regresi yang palsu (spurious) dan jangka pendek yang terjadi karena adanya kointegrasi di antara variabel penelitian.

Metode ini merupakan regresi tunggal yang menghubungkan diferensi pertama pada variabel terikat $(\Delta Y \mathrm{t})$ dan diferensi pertama untuk semua variabel bebas dalam model. Dalam melakukan estimasi, parameter-parameter yang diestimasi harus linier sehingga dipergunakan fungsi log.

Model umum dari ECM adalah sebagai berikut:

$$
\Delta Y=\beta_{0}+\beta_{1} \Delta X_{t-1}+\beta_{2} E C_{t-1}+\varepsilon_{t}
$$

Untuk mengetahui spesifikasi model dengan ECM merupakan model yang valid, dapat dilihat pada hasil uji statistik terhadap residual dari regresi pertama, yang selanjutnya akan disebut Error Correction Term (ECT). Jika hasil pengujian terhadap koefisien ECT signifikan, maka spesifikasi model yang diamati valid.

Model ECM dalam penelitian ini adalah: sehingga timbul fenomena autokorelasi dan juga kita tidak akan dapat menggeneralisasi regresi tersebut untuk waktu yang berbeda. Dalam hal ini, dilakukan uji akar unit melalui metode Augmented Dickey-Fuller dengan hasil sebagai berikut:

Tabel 2. Hasil Uji Akar Unit

\begin{tabular}{lcc}
\hline & Level & $1^{\text {st }}$ Difference \\
\hline Prob. CAR & $0,0213^{* *}$ & $0,0008^{* * *}$ \\
Prob. ROA & $0,0113^{* *}$ & $0,0000^{* * *}$ \\
Prob. FDR & 0,1397 & $0,0000^{* * *}$ \\
Prob. BOPO & 0,7394 & $0,0000^{* * *}$ \\
Prob. Inflasi & $0,0007^{* * *}$ & $0,0001^{* * *}$
\end{tabular}

Sumber: Data diolah

Pada Tabel 2, dapat diketahui bahwa pada pengujian level tidak ada variabel yang stasioner karena nilai probabilitas seluruh variabel besarnya di atas 0,05. Pada $1^{\text {st }}$ difference, seluruh variabel diketahui stasioner mengingat nilai probability seluruh variabel besarnya di bawah 0,05. 
2. Estimasi Persamaan Jangka Panjang Hasil estimasi persamaan jangka panjang pada penelitian ini adalah sebagai berikut:

Tabel 3. Estimasi Jangka Panjang

\begin{tabular}{lcc}
\hline & Coeffiecient & Probability \\
\hline ROA & 0,637504 & $0,0192^{* *}$ \\
FDR & $-0,159798$ & $0,0011^{* * *}$ \\
BOPO & $-0,016747$ & 0,4634 \\
INFLASI & 0,543770 & $0,0069^{* * *}$ \\
\hline Prob.(F-statistic) & \multicolumn{2}{c}{$0,000024^{* * *}$}
\end{tabular}

Sumber: Data diolah

Pada Tabel 3, nilai probabilitas F-statistik sebesar 0,000024, atau lebih kecil dari 0,05, yang menunjukkan speed of adjustment persamaan jangka panjang yang ada adalah valid. Nilai probabilitas variabel ROA $(0,0192)$, FDR $(0,0011)$ dan inflasi $(0,0069)$ yang besarnya di bawah 0,05 menunjukkan bahwa variabel ROA, FDR dan inflasi memiliki pengaruh jangka panjang terhadap variabel CAR.

3. Uji Kointegrasi

Uji kointegrasi digunakan untuk memberikan indikasi awal bahwa model yang digunakan memiliki hubungan jangka panjang. Pengujian kointegrasi pada penelitian ini dilakukan dengan melakukan pengujian Augmented Dicker Fulley Unit Root Test terhadap data residual dengan hasil sebagai berikut:

Tabel 4. Hasil Uji Akar Unit Data Residu

\begin{tabular}{ccc}
\hline Variabel & Probability & Keterangan \\
\hline ECT & $0,0101^{* *}$ & Ada kointegrasi \\
\hline
\end{tabular}

Pada Tabel 4, dapat diketahui bahwa nilai probabilitas variabel ECT besarnya di bawah 0,05 (a). Hal tersebut memberikan informasi bahwa variabel ECT stationer pada level dan secara tersirat menyatakan bahwa variabel CAR, BOPO, FDR, ROA dan inflasi saling berkointegrasi sehingga pengujian dapat dilanjutkan ke tahap estimasi persamaan jangka pendek.

4. Model ECM

Model ECM yang baik dan valid harus memiliki ECT yang signifikan. ECT mengukur respon regressand setiap periode yang menyimpang dari keseimbangan (Iqbal, 2015). Model ECM pada penelitian ini adalah sebagai berikut:

Tabel 5. Model ECM

\begin{tabular}{lcc}
\hline & Coeffiecient & Probability \\
\hline D(ROA) & 0,434927 & $0,0267^{* *}$ \\
D(FDR $)$ & $-0,130214$ & $0,0031^{* * *}$ \\
D(BOPO) & $-0,026381$ & 0,2644 \\
D(INFLASI) & 0,511583 & $0,0016^{* * *}$ \\
ECT(-1) & $-0,553915$ & $0,0119^{* * *}$ \\
\hline \multicolumn{1}{c}{$\quad R^{2}$ Adjusted $R^{2}$} & 0,672610 \\
\multicolumn{2}{c}{ Prob.(F-statistic) } & 0,601438 \\
\hline
\end{tabular}

Sumber: Data diolah

Pada Tabel 5, diketahui nilai probabilitas F-statistik sebesar 0,000053 yang besarnya lebih kecil dari 0,05 (a) dan nilai ECT(-1) yang menunjukkan speed of adjustment negatif dan signifikan sehingga dapat disimpulkan bahwa model ECM ini valid dan berpengaruh secara signifikan dalam jangka pendek maupun jangka panjang. Nilai adjusted $\mathrm{R}^{2}$ sebesar 0,601438 atau 60,14\% menunjukkan bahwa sekitar 39,86\% keragaman variabel CAR dipengaruhi oleh variabel bebas di luar model.

Hasil estimasi persamaan jangka pendek menunjukkan bahwa dalam jangka pendek perubahan ROA, FDR, dan inflasi memberikan pengaruh signifikan terhadap CAR di mana ROA dan inflasi memberikan pengaruh positif pada CAR, sementara FDR berpengaruh negatif. Besar koefisien ECT sebesar 0,553915 mempunyai makna bahwa perbedaan antara CAR dengan nilai 
keseimbangannya sebesar 0,553915 akan disesuaikan dalam waktu 1 tahun.

5. Uji Asumsi Klasik

a. Uji Multikolinieritas
Multikolinearitas menunjukkan adanya hubungan linier antar variabel independen di dalam model regresi. Hasil pengujian multikolineartias antar variabel independen adalah sebagai berikut:

Tabel 6. Hasil Uji Multikolinearitas

\begin{tabular}{cccccc}
\hline & CAR & ROA & FDR & BOPO & Inflasi \\
\hline CAR & 1,000000 & 0,562090 & $-0,453407$ & $-0,108707$ & 0,387205 \\
ROA & 0,562090 & 1,000000 & $-0,008458$ & $-0,555420$ & 0,206103 \\
FDR & $-0,453407$ & $-0,008458$ & 1,000000 & $-0,494266$ & 0,132358 \\
BOPO & $-0,108707$ & $-0,555420$ & $-0,494266$ & 1,000000 & $-0,073588$ \\
Inflasi & 0,387205 & 0,206103 & 0,132358 & $-0,073588$ & 1,000000 \\
\hline
\end{tabular}

Sumber: Data diolah

Hasil pengujian pada Tabel 6 tidak menemukan adanya nilai matriks korelasi yang besarnya di atas 0,85. Dengan demikian, dapat disimpulkan bahwa tidak terdapat masalah multikolinearitas dalam model ini.

b. Uji Heterokedastisitas

Heterokedastisitas dapat menyebabkan penaksiran menjadi bias (Basuki dan Yuliadi, 2014). Pendeteksian heterokedastisitas dilakukan dengan teknik uji white heterokedasticity sebagai berikut:

Tabel 7. Hasil Uji Heterokedastisitas White

\begin{tabular}{lllc}
\hline F-statistic & 0,298197 & $\begin{array}{l}\text { Prob,F } \\
(14,15)\end{array}$ & 0,9854 \\
Obs ${ }^{*} R^{2}$ & 6,531650 & $\begin{array}{l}\text { Prob, Chi- } \\
\text { Square (14) }\end{array}$ & 0,9513 \\
& &
\end{tabular}

Sumber: Data diolah

Nilai probabilitas Chi Square dari Obs* R2 sebesar 0,9513, yang besarnya lebih dari 0,05 menunjukkan bahwa tidak terdapat heterokedastisitas dalam model ECM. c. Uji Autokorelasi

Uji autokorelasi menunjukkan adanya korelasi antara serangkaian observasi (Basuki dan Yuliadi, 2014). Pendeteksian autokorelasi dilakukan dengan teknik lagrange multiplier sebagai berikut:

Tabel 8. Hasil Uji Autokorelasi Lagrange Multiplier

\begin{tabular}{llll}
\hline F-statistic & 3,768475 & Prob,F (3,22) & 0,0641 \\
Obs $^{*} R^{2}$ & 4,071317 & Prob, Chi- & 0,0436 \\
& & Square (3) & \\
& &
\end{tabular}

\section{Sumber: Data diolah}

Nilai prob, Chi Square dari Obs*R2 sebesar 0,0436 yang besarnya lebih kecil dari 0,05 sehingga menunjukkan bahwa tidak terdapat autokorelasi dalam model ECM.

d. Uji Normalitas

Uji normalitas dalam penelitian ini dilakukan dengan teknik uji Jarque-Berra dengan hasil sebagai berikut: 
Tabel 9. Hasil Uji Normalitas Jarque-Berra

\begin{tabular}{lcc}
\hline Jarque-Berra & Probability & Keterangan \\
\hline 0,318033 & 0,852982 & Normal \\
\hline
\end{tabular}

Sumber: Data diolah

Nilai probability sebesar 0,852982 yang besarnya lebih besar 0,05 menunjukkan bahwa data yang digunakan dalam model ECM berdistribusi normal.

e. Uji Linieritas

Uji linieritas dalam penelitian ini dilakukan dengan teknik uji Ramsey Reset sebagai berikut:

\begin{tabular}{lccc}
\hline & Value & df & Probability \\
\hline t-statistic & 0,375793 & 24 & 0,7104 \\
$\begin{array}{l}\text { F-statistic } \\
\text { Likelihood }\end{array}$ & 0,141220 & $(1,24)$ & 0,7104 \\
ratio & 0,176008 & 1 & 0,6748 \\
\hline
\end{tabular}

Sumber: Data diolah

Nilai probabilitas F-statistik sebesar 0,7104 yang besarnya lebih besar dari 0,05 menunjukkan bahwa model ECM yang digunakan sudah tepat.

f. Uji Signifikansi

Hasil estimasi dengan menggunakan model analisis Error Correction Model (ECM) ditampilkan pada tabel berikut:

Tabel 10. Hasil Uji Linieritas Ramsey Reset

Tabel 11. Hasil Regresi Persamaan ECM

\begin{tabular}{cccc}
\hline Variable & Coefficient & t-Statistic & Probabilitas \\
\hline C & 0.000092 & 0.073794 & 0.9418 \\
\hline ROA & 0.434927 & 2.367505 & $0.0267^{* *}$ \\
\hline FDR & -0.130214 & -3.303825 & $0.0031^{* * *}$ \\
\hline BOPO & -0.026381 & -1.144048 & 0.2644 \\
\hline INFLASI & 0.511583 & 3.587163 & $0.0016^{* * *}$ \\
\hline ECT(-1) & -0.553915 & -2.731464 & $0.0119^{* *}$ \\
\hline F-statistic & 9.450522 & & \\
\hline Prob(F-statistic) & $0.000053^{* * *}$ & & \\
\hline Adjusted R-squared & 0.601438 & & \\
\hline Durbin-Watson stst & 2.059850 & &
\end{tabular}

Sumber: Data diolah

Dari tabel di atas, dapat disusun persamaan model ECM sebagai berikut:

$$
\begin{aligned}
\Delta L_{n} C A R_{t}= & 0.000092+0.434927 \Delta R O A_{t}+-0.130214 \Delta F D R_{t}+-0.026381 \Delta B O P O_{t} \\
& +0.511583 \Delta I N F_{t}+-0.553915+\mu_{t}
\end{aligned}
$$

\section{A. Interpretasi Koefisien Jangka Panjang dan Jangka Pendek}

Berdasarkan hasil dari pengujian statistik yang dilakukan pada Tabel 11, dapat diketahui bahwa regresi yang dihasilkan cukup baik untuk menerangkan variabelvariabel yang dapat mempengaruhi Capital
Adequacy Ratio (CAR). Dari keempat variabel independen (ROA, FDR, BOPO, dan Inflasi)

yang dimasukkan ke dalam pengujian statistik dan ekonometrik, ternyata tidak semua variabel berpengaruh secara signifikan dan mempunyai pengaruh jangka panjang ataupun jangka pendek. 
Berdasarkan hasil pengujian yang telah dilakukan di atas, dapat dianalisis sebagai berikut:

\section{Return On Assets (ROA)}

Koefisien jangka panjang ROA sebesar 0.637504 dengan signifikansi 0.0192 . Hal ini berarti dalam jangka panjang, setiap perubahan ROA sebesar 1\% akan mengakibatkan perubahan dalam CAR sebesar $0.637504 \%$. Sedangkan dalam jangka pendek, koefisien ROA sebesar 0.434927 dengan signifikansi 0.0267 , yang berarti setiap peningkatan ROA dalam jangka pendek sebesar $1 \%$ akan menyebabkan perubahan dalam CAR sebesar 0,434927. Karena nilai koefisien dalam jangka panjang maupun jangka pendek ROA menunjukkan nilai signifikansi lebih kecil dari 0,05, maka dapat disimpulkan bahwa ROA berpengaruh signifikan dan positif terhadap CAR sehingga hipotesis yang diajukan yaitu ROA berpengaruh signifikan dan positif terhadap CAR pada Bank Umum Syariah di Indonesia diterima. Hal ini mengindikasikan bahwa perubahan yang terjadi pada ROA akan berpengaruh signifikan terhadap CAR.

Adanya hubungan positif antara ROA dengan CAR dalam jangka panjang maupun jangka pendek memberikan artian bahwa ROA akan membawa dampak dalam jangka panjang maupun jangka pendek. Apabila ROA mengalami kenaikan, maka dalam jangka panjang maupun jangka pendek pengaruh tersebut akan menjadi faktor yang meningkatkan CAR. Semakin besar ROA mengindikasikan keuntungan yang diperoleh Bank Umum Syariah atas asset juga meningkat sehingga dalam jangka panjang maupun jangka pendek akan menambah kemampuan Bank Umum Syariah dalam meningkatkan modal dan hal ini akan meningkatkan CAR.

Hasil penelitian ini mendukung hasil penelitian yang dilakukan oleh Edginarda (2012) dan Sakinah (2013) yang menunjukkan bahwa ROA secara parsial berpengaruh signifikan positif terhadap CAR. Hasil penelitian ini berbeda dengan penelitian Fatimah (2014) yang menunjukkan bahwa ROA berpengaruh negatif signifikan, dan berbeda dengan hasil penelitian Yuliyani (2015) yang menunjukkan bahwa ROA tidak berpengaruh signifikan terhadap CAR.

\section{Financing to Deposit Ratio (FDR)}

Koefisien jangka panjang FDR adalah sebesar -0.159798 dengan signifikansi 0.0011. Hal ini berarti dalam jangka panjang, perubahan FDR sebesar $1 \%$ akan mengakibatkan penurunan CAR sebesar $0.159798 \%$. Sedangkan koefisien jangka pendek FDR sebesar -0.130214 dengan signfikansi 0.0031, yang berarti dalam jangka pendek peningkatan FDR sebesar 1\% akan menyebabkan penurunan CAR sebesar $0.130214 \%$.

Karena nilai koefisien dalam jangka panjang maupun jangka pendek FDR negatif dengan nilai signifikansi lebih kecil dari 0.05, maka dapat disimpulkan bahwa FDR berpengaruh signifikan dan negatif terhadap CAR.

Adanya hubungan negatif antara FDR dengan CAR dalam jangka panjang maupun jangka pendek memberikan artian bahwa FDR akan membawa dampak dalam jangka panjang maupun jangka pendek. Apabila FDR mengalami kenaikan yang disebabkan oleh pembiayaan tinggi sedangkan dana yang dihimpun sedikit, maka dalam jangka panjang maupun jangka pendek dapat menurunkan CAR sehingga kemampuan 
bank dalam mengelola dana masih efektif dan efisien.

Hasil penelitian ini mendukung hasil penelitian yang dilakukan Fatimah (2014) yang menunjukkan bahwa FDR berpengaruh negatif signifikan terhadap CAR. Hasil penelitian ini berbeda dengan hasil penelitian Sakinah (2013) yang menunjukkan bahwa FDR secara parsial memiliki pengaruh positif dan signifikan terhadap CAR.

3. Biaya Operasional terhadap Pendapatan Operasional (BOPO)

Koefisien jangka panjang BOPO adalah 0.016747 dengan signifikansi 0.4634, sedangkan koefisien jangka pendek BOPO adalah -0.026381 dengan signifikansi 0.2644. Dengan demikian, kenaikan BOPO tidak memiliki pengaruh yang signifikan terhadap CAR dalam jangka panjang maupun jangka pendek karena nilai signifikansinya lebih besar dari 0.05 yang berarti bahwa naik atau turunnya BOPO tidak berpengaruh terhadap CAR baik dalam jangka panjang maupun jangka pendek. Hasil penelitian ini berbeda dengan hasil penelitian Edginarda (2012), Yuliyani (2015) dan Fatimah (2014) yang menunjukkan bahwa BOPO memiliki pengaruh signifikan terhadap CAR.

\section{Inflasi}

Koefisian jangka panjang Inflasi sebesar 0.543770 dengan signifikansi 0.0069 yang berarti dalam jangka panjang, perubahan Inflasi sebesar 1\% akan meningkatkan CAR sebesar $0.543770 \%$, sedangkan koefisien inflasi dalam jangka pendek sebesar 0.511583 dengan signifikansi 0.0016 menunjukkan bahwa kenaikan inflasi sebesar $1 \%$ akan menyebabkan perubahan CAR sebesar $0.511583 \%$ dalam jangka pendek. Karena nilai koefisien Inflasi dalam jangka panjang maupun jangka pendek positif dengan nilai signifikansi lebih kecil dari 0.05, maka dapat disimpulkan bahwa inflasi berpengaruh signifikan dan positif terhadap CAR. Hasil penelitian ini mendukung hasil penelitian yang dilakukan oleh Sakinah (2013) yang menunjukkan bahwa Inflasi memiliki pengaruh signifikan positif terhadap CAR.

\section{SIMPULAN}

1. Return On Assets (ROA) dalam jangka panjang ataupun jangka pendek, berpengaruh signifikan positif terhadap CAR pada Bank Umum Syariah di Indonesia. Hal ini mengindikasikan bahwa setiap peningkatan ROA akan mempengaruhi modal bank tersebut sehingga nantinya berimplikasi pada peningkatan CAR.

2. Financing to Deposit Ratio (FDR) dalam jangka panjang dan jangka pendek, berpengaruh signifikan negatif terhdap CAR. Hal tersebut menjelaskan bahwa FDR akan mengakibatkan penurunan CAR dalam jangka panjang dan jangka pendek. Apabila FDR mengalami peningkatan yang disebabkan oleh tingginya pembiayaan, sedangkan dana yang dihimpun sedikit, maka akan berpengaruh terhadap turunnya CAR.

3. Biaya Operasional terhadap Pendapatan Operasional (BOPO) tidak memiliki cukup bukti dalam mempengaruhi CAR.

2. Dalam jangka pendek ataupun jangka panjang, inflasi berpengaruh signifikan positif terhadap CAR.

\section{DAFTAR PUSTAKA}

Basuki, A. T., dan Yuliadi, I., 2014, Elektronik Data Prosesing (SPSS 15 dan EVIEWS 7), Danisa Media, Yogyakarta.

Dendawijaya, L., 2011, Manajemen Pebankan, Ghalia Indonesia, Jakarta. 
Edginarda, C., 2012, “Analisis Pengaruh Rasio Rentabilitas dan Likuiditas terhadap Capital Adequacy Ratio pada Bank Pemerintah di Indonesia Periode 20032010", Skripsi Manajemen, Universitas Hasanudin, Makasar.

Fatimah, S., 2014, "Pengaruh Rentabilitas, Efesiensi, dan Likuiditas Terhadap Kecukupan Modal Bank Umum Syariah", Jurnal Al-Iqtishad, Vol. VI No.1, Januari, hal. 54-72.

Hasan Iqbal. (2015). Pokok-Pokok Materi Statistik 2 (Statistik Inferentif). Jakarta: Bumi Aksara

Kasmir. 2009. Pengantar Manajemen Keuangan. Jakarta: Kencana

Muhammad, 2005. Manajemen Bank Syariah. Yogyakarta: UPP AMP YKPN

Masyhud. Ali. 2006. Manajemen Risiko, Strategi Perbankan Dan Dunia Usaha Menghadapi Tantangan Globalisasi Bisnis. PT. Raja Grafindo Persada, Jakarta

Sakinah, F., 2013, “Faktor-faktor yang Mempengaruhi Capital Adequacy Ratio pada Bank Syariah di Indonesia Periode Maret 2009-Desember 2011", Skripsi Ilmu Ekonomi dan Studi Pembangunan, Universitas Islam Negeri Syarif Hidayatullah, Jakarta.

Yuliyani, 2015, "Pengaruh Assets To Loan Ratio (ALR), Quick Ratio (QR), Return On Assets (ROA), dan Operational Expense To Operational Income (BOPO) terhadap Capital Adequacy Ratio (CAR) pada Bank Umum yang terdaftar di BEI Periode 2009-2013", Jurnal Akuntansi, Universitas Maritim Raja Ali Haji, Tanjung Pinang. 